\title{
Online Instructional Scaffolding and Needs Satisfaction in COVID-19 Pandemic: Evidence from University Students in Ghana
}

\section{Article History}

Received: 21 August, 2021

Revised: 23 October, 2021

Accepted: 28 October, 2021

Published: 4 November, 2021

Copyright $\odot 2021$ Noble Academic Publisher \& Author

\author{
Dandy George Dampson* \\ University of Education, Winneba, Ghana \\ Inuusah Mahama \\ University of Education, Winneba, Ghana \\ Stephen Antwi-Danso \\ University of Education, Winneba, Ghana \\ Peter Eshun \\ University of Education, Winneba, Ghana \\ Richardson Addai-Mununkum \\ University of Education, Winneba, Ghana
}

\begin{abstract}
The COVID-19 pandemic has affected every aspect of education including lecturers and students' engagements. Therefore, this study investigated the effect of online instructional scaffolding on needs satisfaction as experienced by regular undergraduate students in Ghana. Using the descriptive-quantitative research design, the study surveyed 738 students using an online learning platform (VClass). The students were asked to respond to the adapted online instructional scaffolding scale developed by Cho and Cho (2016) and the needs satisfaction scale developed by Johnston and Finney (2010). The data gathered with the adapted scales were analyzed quantitatively using frequencies and percentages and standard linear regression. The study revealed that the majority of the students experienced low levels of online instructional scaffolding $(n=259 ; 35.1 \%)$ and needs satisfaction $(n=254$; $34.4 \%)$. Also, it was found that online instructional scaffolding significantly predicted the need satisfaction of students $(\beta=.45, p=.000)$. It was concluded that the low levels of online instructional scaffolding and needs satisfaction experienced by students are probable precursors to low academic engagement and commitment. Therefore, there is the need to re-orient both lecturers and students to the benefits of online learning so that they could maximize its usage.
\end{abstract}

Keywords: Instructional Scaffolding, Needs Satisfaction, Students, Lecturer and Ghana.

\section{Introduction}

Due to the recent Covid-19 pandemic, faculty of universities have been under increased stress and workloads, which has worsened their already difficult task of balancing teaching, research, and service obligations, as well as maintaining a healthy work-life balance (Houlden and Veletsianos, 2020). According to Hodges et al. (2020), teachers from all backgrounds and ages have been forced to prepare and deliver their classes from their homes, with all of the practical and technological challenges that these online learning platforms, and in many cases, without the benefit of adequate technical support. Apart from that, one of the most significant challenges faced by university teachers has been a lack of pedagogical knowledge required for online instruction. Technical and administrative aspects of online teaching are included in this type of instruction. Furthermore, it includes the pedagogical foundations and knowledge of principles that are required to design for, as well as facilitate, effective online learning experiences (Ching et al., 2018; Kali et al., 2011).

According to Joosten and Cusatis (2020), online learning offers students the opportunity to decide, what, where, when, and how to learn. This is because students assume control over the learning situation and assume ownership of the learning activities. However, online learning requires various abilities of students such as familiarity with technology use, management of time and organization, and interaction using online technologies (Joosten and Cusatis, 2020). It is noted that students who enroll in online courses may have mixed levels of readiness, preparedness, and satisfaction that could affect their academic excellence (Agormedah et al., 2020). To control online learning challenges among students, higher educational institutions (HEIs) can provide resources to help students assess whether they are ready to take 
an online course and measure their levels of satisfaction after they had been engaged (Agormedah et al., 2020; Joosten and Cusatis, 2020). Consequently, lecturers can also provide instructional support via instructional activities that can help students in appraising their preparedness and readiness (e.g., assessment), gaining the needed skills to learn online, and managing their expectations about learning online, which can help increase students' chances for success in an online course (Agormedah et al., 2020; Joosten and Cusatis, 2020). In the case of Ghana, lecturers of high educational institutions (HEIs) were mandated to develop their learning models and upload them onto e-learning platforms to ensure effective instructional discourse at the peak of the COVID-19 pandemic. This paradigm shift appeared not to be problem-free because concerns were raised regarding internet connectivity and online learningrelated challenges by academic faculty, students, and parents (Agormedah et al., 2020).

A growing number of students are taking online courses, and online learning is becoming more common in higher education (Seaman et al., 2018). However, despite the significant expansion of online learning, roughly $23 \%$ of students expressed concern about the quality of instruction and academic support for online courses in higher education (College., 2019). Following the results of a survey of MOOC instructors conducted by Doo et al. (2020), it was found that proper academic assistance and the use of effective instructional strategies were necessary to improve the quality of learning in an online learning environment. Students' engagement in learning and learning outcomes are enhanced when scaffolding is used as an instructional method, which has gained great attention as an effective instructional strategy (Belland et al., 2017). Many scholars have investigated the process of scaffolding as an educational method as a result of the growing interest in this strategy among educators. However, the conclusions of these studies have been inconsistent and even contradictory to date. An example includes Barzilai and Blau (2014), who discovered that conceptual scaffolding had little or no significant effect on learning in synchronous online discussions.

\section{Online Learning and COVID-19}

Technology has made online learning simple (McBrien et al., 2009). In most cases, the capacity to operate a computer connected to a network is required (Cojocariu et al., 2014). Online learning is a tool that can make teaching and learning student-centered, inventive, and adaptable. Learning in synchronous or asynchronous situations using various internet-connected devices (e.g., phones, laptops, etc.) is called online learning. Students can learn and communicate with professors and other students from anywhere (Singh and Thurman, 2019). Asynchronous learning environments are not structured, but synchronous learning settings are. In such a learning environment, content is available through various learning platforms and forums, not live lectures or classes. In such a setting, instant feedback and response are impossible (Littlefield, 2018). Synchronous learning can foster student-teacher interaction (McBrien et al., 2009). So, online learning is used in this study as the application internet-related and computer-related tools in the teaching and learning process in the midst of COVID-19 pandemic in the University of Education-Winneba, Ghana.

The use of online learning in education has grown dramatically in recent years, with numerous benefits being realized as a result of this increase (Allen and Seaman, 2017). The fact that a large number of students are taking their courses online has prompted educators to develop online courses that would boost student learning and instructional effectiveness (Evans, 2014). Various studies have found that online learning can boost student involvement, improve the quality of discussions, and encourage online interactions (Agormedah et al., 2020; Daniel, 2020; Henaku, 2020). By assisting students in resolving emerging challenges, the discussion forum has the potential to increase learning. Mobile technology, such as software and PCs, may make it possible to have quick access to an online learning platform and improve the effectiveness of mobile learning initiatives (Panigrahi et al., 2018). The disadvantages of online learning are seen in student engagement, academic performance, and time consumption, even though multiple studies have found that online learning is more successful than traditional learning when compared to the latter (Adedoyin and Soykan, 2020; Adnan and Anwar, 2020; Mukhtar et al., 2020). Although a considerable percentage of teachers were open to the idea of using an online teaching strategy, many were skeptical, believing that online learning would lower student involvement, resulting in less favourable academic outcomes than traditional face-to-face training. Only a few online teachings and learning activities can adhere to a strict timetable and design (Lederman, 2018; Tallent-Runnels et al., 2006). 


\section{Online Instructional Scaffolding and COVID-19}

We draw on the psycho-pedagogical concept of scaffolding to theoretically frame this work. Scaffolding is derived from the works of Vygotsky (1978) and Wood et al. (1976). The term 'scaffolding' is a metaphor for describing the type of assistance offered in support of learning by a teacher or coworker. The teacher helps the student master in the scaffolding process a task or concept which the student cannot understand autonomously. The teacher offers help with only skills beyond the capacity of the student. The term "online instructional scaffolding" refers to the support offered by teachers or instructors via the use of technological resources. These teachers will make use of a variety of technical tools and resources that will aid them in their classroom instruction. Students can benefit from the virtual learning environment in the same way: they may use it to communicate with their peers while also having their progress assessed regularly by their instructors. To be effective, such a strategy must be supported by a systematic framework to avoid pupils becoming frustrated if they do not succeed in their learning objectives. This implies that online educators perform scaffolding in a manner that is appropriate for the needs of their students (Jumaat and Tasir, 2014). Blumenstyk (2018) predicts that the use of online learning environments will continue to grow at a rapid pace in higher education over the next decade. This is primarily since online learning environments typically provide access to learning resources, tools, and communication media regardless of where students live or travel. Provide sufficient infrastructure to provide simple and convenient access to various learning tools throughout a university or institution can, in turn, encourage flexible and self-directed learning. For example, the rapid rise of massive open online courses (MOOCs) has accelerated the growth of online learning options and educational possibilities to meet the requirements and motivation of learners everywhere (Milligan and Littlejohn, 2017). As a result of technological improvements, students now have more learning possibilities that are not limited by time constraints. Recent surveys and research findings, on the other hand, have found several problems with online learners, including low learning engagement and poor-quality instruction (Doo et al., 2020). Learners require proper instructional support, such as timely and suitable scaffolding, to improve their online learning outcomes. This, in turn, makes learning more relevant and engaging (Oliver and Herrington, 2003). According to Roddy et al. (2017), the nature of the online education environment also means that course delivery must compensate for the lack of immediate physical infrastructure by depending more heavily on asynchronous ways of communication to compensate for the loss of physical infrastructure. In terms of key outcomes such as student academic achievement (McPhee and Söderström, 2012) and student satisfaction (McPhee and Söderström, 2012), online instructional scaffolding has been proven to be equivalent to on-campus contexts (Palmer, 2012). For online courses, the factors that contribute to a successful orientation include comprehensive overviews of the course structure, recommended time commitments and expectations of students, familiarization with the required instructional media and software, and guidance on the communication tools that will be used during student-staff interactions. To deliver this information in an online context, a significant revision of how these programs are created is required (Smyth and Lodge, 2012). Relating to this study, online instructional scaffolding is used as the assistance and support offered to students to navigate the online learning platform provided by the University of Education-Winneba, Ghana. This assistance and support systems are provided by the HEI but the directed by lecturers.

Ak (2016) study on computer-based scaffolding in Turkey revealed that students' task-related learning activities are improved when technology-based scaffolding is utilized. Kim J. Y. and Lim (2019) conducted a study in which they investigated the effects of supporting (i.e., conceptual) and reflective (i.e., meta-cognitive) scaffolding on problem-solving performance and learning outcomes in an online illstructured problem-solving environment in Korea. The results showed that the reflective scaffolding group outperformed the supporting scaffolding group in terms of problem-solving performance and learning outcomes compared to the control group. They also discovered that there was a statistically significant interaction between the sort of scaffolding used and the meta-cognitive effects in an online learning environment, according to the researchers (Yilmaz and Yilmaz, 2019; Zhang and Bonk, 2009).

Cochran et al. (2016) conducted a focus group study with students to determine general student perceptions of their online learning environment across courses rather than focusing on single evaluations for single courses. They found that students had positive perceptions of their online learning environment across courses. In this study, the students expected that a teacher's presence was extremely important to them and that some of the assignments assigned to them online appeared to be designed to keep them occupied rather than to provide them with real learning opportunities. Students' impressions of blended learning in a particular module were investigated by Glogowska et al. (2011) in a study that was identical to the one described above but with nursing students. They noticed that, although they were aware of the 
disadvantages of working online, these students were thrilled about the ease that blended learning provided for them. Students' perceptions of teaching and social presence in online and face-to-face learning contexts were examined by Bowers and Kumar (2017), who discovered that students were more aware of teacher and social presence in the online version of the course than in the face-to-face version. Kim K. J. et al. (2005) discovered that the availability of online courses was the most important factor in Master of Business Administration students' perceptions of online learning environments, while also discovering that the convenience of online learning was a key factor in their perceptions of online learning environments. This was followed by discussions about the course's overall quality, length, and cost. Picciano (2002) investigated student perceptions of the level and quality of contact in an online course and discovered that there was a substantial relationship between perceived student performance in online courses and the level and quality of interaction. His research revealed that, while strong student interactions had a considerable impact on the quality of written evaluations, the results of the examinations did not differ significantly from one another. The most noteworthy finding of this study, however, was the extremely high association between student social presence and student perceptions of learning, which was revealed in the results. A study conducted by Russo and Benson (2005) looked into the relationship between how students interpret interactions that occur in the online environment and their attitude toward and satisfaction with their level of learning and found that it was significant. This "online presence" extended to the instructor's online input for the course, which was found to be substantially connected with student course satisfaction and learning outcomes. Further evidence of the importance of the teacher's social and cognitive presence in an online learning situation has been offered by other researchers as well (Hosler and Arend, 2012; Kear et al., 2014). These studies discuss the importance of online course elements such as interaction, online presence, personal contact, and social presence.

\section{Students' Need Satisfaction and COVID-19}

Ryan and Deci (2000) propose that the satisfaction of three psychological needs for autonomy, competence, and relatedness are critical in the emergence of self-determined goal-direction. A large body of variable-centered research has demonstrated that the satisfaction of these psychological needs, as well as autonomous (engaging in an activity out of pleasure or volition) and controlled (engaging in an activity because of internal or external pressures) motivations, have distinct effects on a variety of educational outcomes (Cordeiro et al., 2016; Stolk et al., 2018; Wang R. et al., 2017). According to research conducted in a variety of cultural contexts, students' psychological needs satisfaction appears to be capable of explaining important educational outcomes such as engagement and achievement (Stolk et al., 2018). Psychological needs satisfaction appears to be even more strongly related to these outcomes than autonomous and controlled forms of motivation (Kanat-Maymon et al., 2015).

The COVID-19 pandemic did not only change the instructional strategies among schools but also affected the needs of students, who directly receive tuition through online platforms. Students' needs are very important for their survival in higher education. As a motivator, the unsatisfied needs of students may have a debilitating effect on their psychological well-being. As described by Ryan and Deci (2000), human beings yearn for a sense of self-determination, competence, and connectedness. Individuals' psychological well-being is dependent on their ability to meet these demands, which can, in turn, fuel motivation and behavior. A recent study conducted by Mahama et al. (2021) indicates that COVID-19 affected students in many ways including their learning styles, attachment, and sense of belonging, which in a way could affect the needs of students.

Deci and Ryan (2000) coined the term "need satisfaction", which implies needs for autonomy, competence, and relatedness. Autonomy contributes to a sense of ownership over actions and a sense of psychological and internal freedom. Competence is the capability of engaging in activities that allow people to apply and expand their knowledge. Finally, the need for relatedness refers to an individual's sensation of warmth, bonding, care, or a sense of belonging to a community. (Vansteenkiste et al., 2020). Individual growth, adaptability, integrity, and well-being are all dependent on meeting these psychological demands (Deci and Ryan, 2000). The importance of needs in promoting students' emotions and motivation has been widely recognized (Milyavskaya and Koestner, 2011; Vansteenkiste et al., 2020), academic success (Wang Y. et al., 2019), psychological well-being (Yu S. et al., 2018), and beneficial parenting style (Schiffrin et al., 2014). Thus, numerous notable ideas in developmental and educational psychology are established with the basic psychological needs of learners in mind. Before the COVID-19 outbreak, students had more opportunities to receive direct feedback from lecturers (the need for competence), to discuss and learn with peers during and after classes (the need for relatedness), to choose how and where to learn (e.g., using libraries, learning with friends at home; they need for 
autonomy), and to engage in university and scholastic activities. Students have been attending online courses in place of traditional courses since social limitations were established. Additionally, students have a restricted number of opportunities to participate in social and university activities. Schwinger et al. (2020) conducted a recent study on the effect of lockdown measures on residents' basic psychological needs fulfillment in Germany and discovered significant decreases in the fulfillment of the demand for autonomy. Additionally, the study found that lockdown measures had the greatest effect on autonomy satisfaction, which was connected with decreased well-being and a rise in mental health disorders such as anxiety and despair. Needs satisfaction is used in this study as the feelings students experience as they perceive their wishes and expectations are met as they use online learning platforms in the University of Education-Winneba, Ghana. These needs can only be satisfied when challenges encountered in the process of learning are duly mitigated by their lecturers. However, the needs of students are varied and complex within the online higher education space, hence, a holistic appreciation of such needs is essential for meeting their expectations by constantly monitoring and improve the online systems for the satisfaction of students and related stakeholders by higher education managers.

Numerous empirical investigations have been conducted to ascertain the impact of the COVID-19 outbreak on institutions of higher education (Hahn et al., 2021; Hajek and Kernecker, 2020; Rahman et al., 2021; Seyfeli et al., 2020). These studies found that students faced increased academic and psychological challenges during "digital" semesters. They expressed concerns regarding the quality of online course delivery, expressed uncertainty about course topics, and expressed mistrust in guidance obtained from distant faculty members (Traus et al., 2020). While Studitemps GmbH and University. (2021) discovered no effect on students' need satisfaction with the study situation following the outbreak, Marczuk et al. (2021) discovered a substantially low level in study satisfaction as a result of impaired social integration. Both analyses anticipated a long-term increase in dropouts as a result of the COVID-19 pandemic, but neither study discovered an increase in actual dropouts in any of the academic semesters. According to (Chiu T. K. F., 2021a; Chiu T. K., 2021b), three innate requirements must be met during a learning assignment for students to be motivated to complete it. As a result, electronic learning environments should be built to meet these three requirements to encourage student involvement. Chiu T. K. F. (2021a) conducted a study that investigated teachers' digital support for student engagement and needs satisfaction. According to the findings of the study, teachers' perceived autonomy, competence, and relatedness support received from the LMS were significantly influenced by their digital support, resulting in higher levels of student engagement. This means that the recommended support solutions were successful in meeting the three innate demands of students when studying with resources and/or completing assignments online for blended learning.

\section{The Ghanaian Context}

In Ghana, higher educational institutions have been implementing novel instructional methodologies to mitigate the effect of COVID-19 learning by facilitating students' transitions and maintaining a healthy educational atmosphere (Agormedah et al., 2020; Henaku, 2020; Mahama et al., 2021). Some of these methods include the use of interactive online instructional platforms, communication with students regarding the progress of examinations social media platforms, and offering students a variety of teaching and learning opportunities. According to Mahama et al. (2021), COVID-19 has placed a lot of demands on students towards their academic adjustment. Mahama et al. (2021) note that, "there is a significant developmental shift in academic engagement between educational instructors and their students, where this shift seems to have created new responsibilities for students in terms of managing their peer attachments, making efforts to employ the most effective learning styles, and developing a sense of belonging to their respective institutions" (p. 176). Aside from preventing the escalation of the various variants of the COVID-19 pandemic, most universities in Ghana have adopted the blended mode of learning (face-to-face and online) with fewer physical contact hours and more online hours. This strategy is laudable (Yu Z., 2021) but appears to burden students more because of their inadequate knowledge in using online platforms. Whether face-to-face learning or online learning, the success of every academic interaction between a teacher and a student depends on the proper guidance and direction of the teacher. The teacher implements every learning strategy. As such, the teacher should be in the right position with the right skills and technology to spearhead the teaching and learning process. However, when teachers seem not to possess the required skills and abilities or fail to guide the teaching and learning process appropriately, it might affect their instructional scaffolding skills and as well, the needs of their students. In the COVID-19 pandemic, teachers' online instructional scaffolding is needed more than expected because most learners appear to lack the required knowledge in navigating most 
online learning platforms in Ghana. Online instructional scaffolding is usually recommended in periods of pandemic (Cho and Cho, 2016; Clinefelter et al., 2019; Jumaat and Tasir, 2014), however, it is unknown whether the online learning method is effective and efficient in creating a learning atmosphere that meets students' needs, facilitating students' engagement, reducing students' turnover intentions, and reducing psychological health risks. This study, therefore, sought to determine the effect of online instructional scaffolding experienced by students on their need satisfaction. On this note, the researchers addressed the following questions and hypothesis:

1. What is the level of instructional scaffolding experienced by undergraduate students in University of Education-Winneba, Ghana?

2. What is the level of need satisfaction as experienced by undergraduate students in University of Education-Winneba, Ghana?

3. $\mathbf{H}_{\mathbf{1}}$ : Online Instructional Scaffolding experienced by students will have an effect on their needs satisfaction in the University of Education-Winneba, Ghana

\section{Methodology}

The researchers employed a descriptive-quantitative design in determining the effect of online instructional scaffolding on the need satisfaction of students. The chosen design was appropriate for the study because quantitative data were collected to enable the quantification of the findings of the study. Students of one public university in Ghana participated in this study. The choice of this university was instructive, given its commitment and demonstrated competence in providing online learning opportunities for students during the Covid-19 pandemic. An online sample of 738 out of 27,321 regular undergraduate students' population were used for the study. Respondents were selected through opt-in volunteer sampling (Fricker, 2016). This technique is deemed appropriate for online surveys (Fricker, 2016). A solicitation notice was posted on the university's learning management system from where volunteers self-selected to participate in the study. The data were collected using google forms routed through Virtual Classroom platforms (VClass) of the University of Education, Winneba in Ghana. By this decision, only students who experienced online learning were able to participate in this study. Again, an equal opportunity was provided to each person using this platform to partake in the study. The sample included both male $(\mathrm{n}=456 ; 61.8 \%)$ and female $(\mathrm{n}=282 ; 38.2 \%)$ respondents who were pursuing various academic programmes. The mean age of the respondents was $(M=26.72 \pm S D=5.32 \pm)$ with the implication that most of the respondents were neither too young nor too old. This nullifies potential biases arising out of variation in their digital competencies as categorized by Prensky (2001). The sample size for the study was adequate based on Apuke (2017) and Krejcie and Morgan (1970) perspectives. According to these scholars, popupaltion size of 27,000 should have a sample size of 379 but the current study's sample size far exceeded the suggestion, hence its appropriateness. The instruments used for the data collection were adapted scales. Specifically, the online instructional scaffolding scale developed by Cho and Cho (2016) was used. The scale had 12-items $(\alpha=.88)$ on a 7-point Likert scale anchored between $1=$ not true at all and $7=$ very true (see Appendix Section B). Again, the basic need satisfaction scale developed by Johnston and Finney (2010) was used. The scale had 21-items $(\alpha=.77)$ with three dimensions: autonomy competence and relatedness on a 7-point Likert scale anchored between $1=$ not true at all and $7=$ very true (see Appendix Section C). The some few modifications were made on the statements of the adapted scales to meet the context and culture of the study area. The data collected with these scales were analysed descriptively (frequencies and percentages) and inferentially (regression).

\section{Results}

The aim of this study was ascertain the effect of online instructional scaffolding on students' needs satisfaction. In performing the analysis, the researchers tested assumption using descriptive statistics. Table 1 presents the results:

Table 1. Test of Assumptions

\begin{tabular}{|l|l|l|l|l|l|l|l|l|l|l|}
\hline \multirow{2}{*}{ V } & N & Min. & Max. & \multicolumn{2}{|l|}{ Mean } & SD & Skewness & \multicolumn{2}{|l|}{ Kurtosis } \\
\cline { 2 - 11 } Stat. & Stat. & Stat. & Stat. & S. E & Stat. & Stat. & S. E & Stat. & S. E \\
\hline OIS & 738 & 14.00 & 84.00 & 69.18 & .475 & 12.90 & -1.04 & .09 & .876 & .18 \\
\hline NS & 738 & 27.00 & 147.0 & 101.86 & .616 & 16.74 & .020 & .09 & 1.290 & .18 \\
\hline
\end{tabular}

$\boldsymbol{V}=$ Variable, $\boldsymbol{O} \boldsymbol{I S}=$ Online Instructional Scaffolding, $\boldsymbol{N S}=$ Needs Satisfaction

Online Data (2021) 
Table 1 indicates the skewness of data based on custom rule values ranged between +1 and -1 and kurtosis custom rule values ranged between +1 and -1 . Referring to online instructional scaffolding, it produced skewness statistic of -1.04 and kurtosis statistic of.876 this implied that distribution for online instructional scaffolding was skewed to the left while kurtosis produced negative value, making the data leptokurtic. This indicates that the majority of the responses are above the average/midpoint in the normal curve (mean and median less than the mode). Referring to needs satisfaction, it produced a skewness statistic of .020 and a kurtosis statistic of 1.290. This implied that the distribution for needs satisfaction was skewed to the right while kurtosis produced a positive value, making it platykurtic kurtosis (positive kurtosis shows distribution that is peaked and possessed thick tails). This explained that the majority of responses were below the average/midpoint on the normal curve (mean and median greater than the mode). Above all, the distribution was normal for both online instructional scaffolding and needs satisfaction.

\section{What Is the Level Of Online Instructional Scaffolding Experienced By Undergraduate Students?}

Table 2. Levels of Online Instructional Scaffolding as Experienced by Students $(n=738)$

\begin{tabular}{||l|l|l|}
\hline Levels & Frequency & Percent \\
\hline Low Level & 259 & 35.1 \\
\hline Moderate Level & 249 & 33.7 \\
\hline High Level & 230 & 31.2 \\
\hline
\end{tabular}

Source: Online Data (2021)

Table 2 shows results on the level of instructional scaffolding experienced by undergraduate students in the period of COVID-19 outbreak. The results show that majority of students experienced low levels of online instructional scaffolding. This means that lecturers are less likely to direct students concerning what to do and what not with their online classes in the period of COVID-19. The current study findings contradict the study finding of Cochran et al. (2016). In their focus group study, they found that students possessed positive perceptions of the online learning environment across the courses they took. The revelation from Cochran et al. (2016) study occurred due to the higher expectation students had on their teachers' ability to guide them through the online learning platforms.

\section{What Is the Level of Needs Satisfaction as Experienced by Students?}

Table 3. Levels of Needs Satisfaction as Experienced by Students $(n=738)$

\begin{tabular}{|c|c|c|}
\hline Level & Frequency & Percent \\
\hline \multicolumn{3}{|c|}{ Autonomy Dimension } \\
\hline Low Level & 271 & 36.7 \\
\hline Moderate Level & 246 & 33.3 \\
\hline High Level & 221 & 29.9 \\
\hline \multicolumn{3}{|c|}{\begin{tabular}{|l|} 
Competence Dimension \\
\end{tabular}} \\
\hline Low Level & 272 & 36.9 \\
\hline Moderate Level & 265 & 35.9 \\
\hline High Level & 201 & 27.2 \\
\hline \multicolumn{3}{|c|}{ Relatedness Dimension } \\
\hline Low Level & 260 & 35.2 \\
\hline Moderate Level & 242 & 32.8 \\
\hline High Level & 236 & 32.0 \\
\hline \multicolumn{3}{|c|}{ General Needs Satisfaction } \\
\hline Low Level & 254 & 34.4 \\
\hline Moderate Level & 250 & 33.9 \\
\hline High Level & 234 & 31.7 \\
\hline
\end{tabular}

Source: Online Data (2021) 
Table 3 shows results on the need satisfaction of students in the period of COVID-19. The results indicate that majority of the respondents possessed a low level of need satisfaction $(n=254 ; 34.4 \%)$. This implies that students' needs were not met in the academic environment in as much as online learning in the period of COVID-19 is concerned. The finding might be as a result of the fact that management of the University of Education, Ghana, where these respondents were selected have not yet appreciated the needs of students in online learning, hence their inability to mitigate the students in a traditional classroom system and the needs of students in online learning platforms. The current study findings corroborate with Marczuk et al. (2021). In their study among German students, they found that students experienced low need satisfaction because of impaired social integration between them and their teachers. However, the current study findings debunked Studitemps GmbH and University. (2021) study finding, which revealed that there was no COVID-19 effect on the need satisfaction of students.

$\mathrm{H}_{1}$ : Online Instructional Scaffolding experienced by students will have an effect on their needs satisfaction

Table 4. Instructional Scaffolding Predicting Students' Need Satisfaction

\begin{tabular}{|l|l|l|l|l|l|l|l|l|l|l|}
\hline Variable & $\mathbf{R}$ & $\mathbf{R}^{\mathbf{2}}$ & Adj. $\mathbf{R}^{\mathbf{2}}$ & $\mathbf{B}$ & $\mathbf{B}$ & $\mathbf{t}$ & S. E. & F & Sig. & $\mathbf{P}$ \\
\hline OIS-NS & .447 & .200 & .199 & .58 & .45 & 13.6 & .043 & 183.64 & .000 & .000 \\
\hline
\end{tabular}

$\boldsymbol{O I S = I n s t r u c t i o n a l ~ S c a f f o l d i n g ~ ( I n d e p e n d e n t ~ V a r i a b l e ) ; ~} \boldsymbol{N S}=$ Need Satisfaction (Dependent Variable)

Source: Online Data (2021)

The researchers investigated the effect of online instructional scaffolding on students' need satisfaction as shown in Table 4. The results indicate that there was a significant positive but moderate relationship ( $r=.447)$ between online instructional scaffolding and students' need satisfaction. This implies that the higher students feel they are being helped by their lecturers in online learning, the more they become satisfied and assume that their learning needs are met. Based on the moderate relationship established, it was appropriate to establish how the independent variable (IS) predicted the dependent variable (NS). The results indicate that online instructional scaffolding explained $20.0 \%$ of the variance in students' need satisfaction $\left[\mathrm{R}^{2}=.200, F(1,736)=183.64, \mathrm{p}=.000\right]$. It was found that online instructional scaffolding positively and significantly predicted students' need satisfaction $(B=.45, p=.000)$ with an effect size of .24 been small. The findings imply that a unit increase in online instructional scaffolding experienced by students would lead to a unit increase in their need satisfaction. The current study finding confirms the study finding of Chiu T. K. (2021). In a study among students concerning digital support offered by teachers to their students in an online learning situation, the study revealed that students indicated their teachers' digital support was high and as well, teachers' digital support predicted students' need satisfaction.

\section{Implication for Practice and Policy}

The low levels of online instructional scaffolding and needs satisfaction experienced by students are probable precursors to low academic engagement and school withdrawal. This is based on the fact that the teachers who are assumed to possess the required knowledge and skills to help students to navigate their online learning platforms seem to be having less knowledge and skills, hence students' feeling of dissatisfied with the whole online learning mode. This may imply that university lecturers are not much conversant with the online teaching and learning platforms, hence their inability to adequately use to the benefit of those they teach. As it stands, the study revelation gives an acute contrast to the statement that providers of online teaching and learning services have demonstrated that online teaching and learning is crucial in reducing early dropout rates, raising self-confidence, and strengthening the students' sense of belonging (Tomei et al., 2009). The issue of inadequate online instructional scaffolding and low need satisfaction experienced by students cannot be the sole responsibility of faculty members but the university as a driver of the online teaching and learning processes. It is possible that the orientation programme designed by the university and given to lecturers to help their students might not be adequate, hence their inability to scaffold the online learning process for their students. According to Cannady (2015), many universities that provide online teaching and learning opportunities to their students do not require them to participate in an adequate orientation program before the start of the enrolment, hence students' inability to appreciate and use these facilities. This is attributed to the difficulty experienced by most universities in coming up with proper online teaching and learning orientation programs. As a result of the difficulty in designing effective online orientation programs, Cannady (2015) study found that up to 
29 percent of institutions only offer on-campus orientation events, even though they offer full-time online teaching and learning activities. This number is particularly troubling because there is compelling evidence to suggest that comprehensive orientation programs are critical to ensuring the success of online learning for lecturers and students in general.

\section{Conclusion and Recommendations}

The outcome of this study is revealing, intriguing and paradoxical. Prensky (2001) distinction of digital immigrants from digital natives implies that generally, lecturers (immigrants) are expected to be less knowledgeable in technology than students (natives). Ironically, students appear to have higher expectation that their lecturers will provide a higher level of instructional scaffolding. Rightly so because in the context of academia where a clear dichotomous power differential exist between lecturers (as the knowers) and students (as the less knowledgeable), its stands to reason that students will expect more, regardless of perceived low competencies of lecturers in ICT. Consequently, it has become imperative that lecturers double-up efforts at upgrading themselves in terms of digital competencies. Whereas technological advancement has induced a lot more of automated services in industry, technological application in teaching is different. Digital tools still require pedagogical skilfulness on the part of teachers and instructional scaffolding is one of them. It is becoming clearer that students will not give any conssessions in their expectation of online instructional scaffolding.

In any online learning setting, students should know what instructors expect of them and what they may anticipate from them. Instructors can help students understand policies by presenting them prominently on their websites. These policies will benefit both instructors and students by simplifying elearning course management. Again, positive attitudes towards online learning can help students overcome some of the possible hurdles. For example, being focused during online classes or being motivated is critical for online learning success. Strong attitudes also help students use ICT efficiently and make the most of new technologies for learning. Self-regulation and intrinsic drive to study are significant factors in enhancing school performance in general, but may be especially vital if online learning continues. Students' attitudes and dispositions are heavily influenced by parental and teacher support as well as role models. Teachers' support can help students establish good attitudes towards learning and optimize their capacity to take advantage of online learning options.

Management of higher education institutions must take clues from these findings to design cuttingedge training programmes for its staff in order to keep them relevant in post-COVID-19 $21^{\text {st }}$ Century. Faculties in higher education need to appreciate that online learning differs significantly from traditional modes in terms of applicable pedagogy. Thus, teacher-centred pedagogical strategies are less useful in online environments. Lecturers need to upgrade their skills in learner-centred pedagogies, utlising active learning and guided discovery techniques in order that they are able to create a more useful learning experiences for their students.

Lecturers need support to incorporate technology effectively into their teaching practices and methods and help students overcome some of the difficulties that are associated with this form of learning environment. Supporting teachers' training about the use of digital resources for pedagogical practice and promoting teaching practices adapted to this context is key to ensure that ICT is leveraged effectively. Support of online learning for lecturers include faculty development, pedagogical and technology training, peripheral roles, policies, and feedback have been explored in the context of faculty effectiveness. Faculty development encompasses both technology and pedagogy; and undoubtedly, both lead to teaching effectiveness. According to Mueller et al. (2013), faculty development programming is one of areas of focus identified to connect adjunct faculty to fulltime faculty. Focused on effective instructional strategies for online learning, the programming should be asynchronous and web-based to meet the time and location constraints of all faculty (Mueller et al., 2013).

Finally, this study utlising only students presents only one side of the narrative in terms of online instructional scaffolding. A lot more research is needed both in terms of approach and respondents to unearth lived experiences of students and instructors in online instructional scaffolding. Future research will benefit the academy with qualitative studies that will explore the phenomenon from subjectivist paradigms in order to provide a more holistic appreciation of online instructional scaffolding.

\section{Limitation}

This work is limited by the context of applicability. All respondents were from a single university in Ghana and their experiences might not be easily extended to other universities. Regardless, readers may do cautious generalisations in situations where contextual circumstances are similar. 


\section{References}

Adedoyin, O. B. and Soykan, E. (2020). Covid-19 pandemic and online learning: the challenges and opportunities. Interactive Learning Environents, 1(1): 1-13.

Adnan, M. and Anwar, K. (2020). Online Learning amid the COVID-19 Pandemic: Students' Perspectives. Online Submission, 7(2): 1-10.

Agormedah, E. K., Henaku, E. A., Ayite, D. M. K. and Ansah, E. A. (2020). Online learning in higher education during COVID-19 pandemic: A case of Ghana. Journal of Educational Technology and Online Learning, 3(3): 183-210.

Ak, S. (2016). The Role of Technology-Based Scaffolding in Problem-Based Online Asynchronous Discussion. British Journal of Educational Technology, 47(4): 680-93. https://doi.org/10.1111/bjet.12254

Allen, I. E. and Seaman, J. (2017). Digital learning compass: Distance education enrollment report 2017. Babson Survey Research Group, e-Literate, and WCET.

Apuke, O. D. (2017). Quantitative Research Methods: A Synopsis Approach. Kuwait Chapter of Arabian Journal of Business and Management Review, 33(5471): 1-8.

Barzilai, S. and Blau, I. (2014). Scaffolding Game-Based Learning: Impact on Learning Achievements, Perceived Learning, and Game Experiences. Computers and Education, 70: 65-79. https://doi.org/10.1016/j.compedu.2013.08.003

Belland, B. R., Walker, A., Kim, N. J. and Lefler, M. (2017). Synthesizing Results From Empirical Research on Computer-Based Scaffolding In Stem Education: A Meta-Analysis. Review of Educational Research, 87(2): 309-44. https://doi.org/10.3102/0034654316670999

Blumenstyk, G. (2018). Online learning is misunderstood. Here's how. The Chronicle of Higher Education. https://www.chronicle.com/newsletter/the-edge/2018-08-07

Bowers, J. and Kumar, P. (2017). Students' perceptions of teaching and social presence: A comparative analysis of face-to-face and online learning environments Blended Learning: Concepts, Methodologies, Tools, and Applications: IGI Global. International Journal of Web-Based Learning and Teaching Technologies (IJWLTT), 10(1): 1-18. 10.4018/ijwltt.2015010103

Cannady, R. E. (2015). Under the Microscope: Looking at Libraries and Online Orientations. Journal of Library \& Information Services in Distance Learning, 9(4): 289-303.

Ching, Y. H., Hsu, Y. C. and Baldwin, S. (2018). Becoming an Online Teacher: An Analysis of Prospective Online Instructors 'Reflections. Journal of Interactive Learning Research, 29(2): 145-68. https://doi.org/10.24059/olj.v22i2.1212

Chiu, T. K. (2021). Digital support for student engagement in blended learning based on selfdetermination theory. Computers in Human Behaviour:

Chiu, T. K. (2021b). Student Engagement in K-12 Online Learning Amid COVID-19: A qualitative Approach From a Self-determination Theory Perspective. Interactive Learning Environments, 5(2): 1-14. https://doi.org/10.1080/10494820.2021.1926289

Chiu, T. K. F. (2021a). Applying the Self-Determination Theory (Sdt) To Explain Student Engagement In Online Learning During the Covid-19 Pandemic. Journal of Research on Technology in Education, 4(2): 1-17. https://doi.org/10.1080/15391523.2021.1891998

Cho, M. H. and Cho, Y. (2016). Online Instructors' Use of Scaffolding Strategies To Promote Interactions: A Scale Development Study. The International Review of Research in Open and Distributed Learning, 17(6): 55-69. https://doi.org/10.19173/irrodl.v17i6.2816

Clinefelter, D. L., Aslanian, C. B. and Magda, A. J. (2019). Online College Students 2019: Comprehensive Data on Demands and Preferences. Louisville KY: Wiley edu, LLC.

Cochran, J. D., Baker, H. M., Benson, D. and Rhea, W. (2016). Business Student Perceptions of Online Learning: Using Focus Groups For Richer Understanding of Student Perspectives. Organization Management Journal, 13(3): 149-66.

Cojocariu, V. M., Lazar, I., Nedeff, V. and Lazar, G. (2014). SWOT Analysis of E-Learning Educational Services from the Perspective of Their Beneficiaries. Procedia-Social and Behavioural Sciences, 116(5): 1999-2003.

College., B. (2019). Online education trends report. https://www.bestcolleges.com/research/annual-trendsin-online-education/on08/2/2021

Cordeiro, P., Paixão, P., Lens, W., Lacante, M. and Luyckx, K. (2016). The Portuguese Validation of the Basic Psychological Need Satisfaction and Frustration Scale: Concurrent and Longitudinal Relations to Well-Being and Ill-Being. Psychologica Belgica, 56(3): 193.

Daniel, J. (2020). Education and the COVID-19 Pandemic. Prospects, 49(1): 91-96. 
Deci, E. L. and Ryan, R. M. (2000). The" what" and" why" of Goal Pursuits: Human Needs and the Selfdetermination of Behaviour. Psychological Inquiry, 11(4): 227-68.

Doo, M. Y., Tang, Y., Bonk, C. J. and Zhu, M. (2020). MOOC Instructor Motivation and Career and $\begin{array}{llll}\text { Professional Development. } \quad \text { Distance } & \text { Education, }\end{array}$ https://doi.org/10.1080/01587919.2020.1724770

Evans, H. K. (2014). An experimental investigation of videotaped lectures in online courses. Technological Trends, 58(3): 63-70.

Fricker, R. D. (2016). Sampling Methods for Online Surveys. The SAGE Handbook of Online Research Methods, 12(3): 184-202.

Glogowska, M., Young, P., Lockyer, L. and Moule, P. (2011). How 'blended' is Blended Learning?: Students' Perceptions of Issues Around the Integration of Online and Face-To-Face Learning in A Continuing Professional Development (Cpd) Health Care Context. Nurse Education Today, 31(8): 887-91.

Hahn, E., Kuhlee, D. and Porsch, R. (2021). Institutional and Individual Factors Influencing the Stressful Experience of Teacher Training Students in the Corona Pandemic: The Education System In Times of Crisis. Empirical Findings, Consequences, and Potentials For Teaching and Learning, 3(2): 221-37.

Hajek, P. and Kernecker, T. (2020). CoV19-Maßnahmen. Online-Befragung Studierende. Peter Hajek Public Opinion Strategies. https://www.bmbwf.gv.at/dam/jcr:71063eaf-86d1-4d80-8d31d023cdbbcd0e/Pr\%C3\%A4sentation Studierende Corona Krise.pdfon25/07/2021

Henaku, E. A. (2020). COVID-19 Online Learning Experience of College Students: The Case of Ghana. International Journal of Multidisciplinary Sciences and Advanced Technology, 1(2): 54-62.

Hodges, C., Moore, S., Lockee, B., Trust, T. and Bond, A. (2020). The Difference Between Emergency Remote Teaching and Online Learning. Educause Review, 5(3): 18-27. https://er.educause.edu/articles/2020/3/the-difference-between-emergency-remote-teaching-andonline-learning

Hosler, K. A. and Arend, B. D. (2012). Strategies and principles to develop cognitive presence in online discussions. In Z. Akyol \& D. R. Garrison (Eds.), Educational communities of inquiry: Theoretical framework, research and practice. Hershey, Pennsylvania: IGI Global.

Houlden, S. and Veletsianos, G. (2020). Coronavirus Pushes Universities to Switch to Online Classes But are They Ready? The Conversation. 2(5): 12-21. https://theconversation.com/coronaviruspushes-universities-to-switch-to-online-classes-butarethey-ready-132728

Johnston, M. M. and Finney, S. J. (2010). Measuring Basic Needs Satisfaction: Evaluating Previous Research and Conducting New Psychometric Evaluations of The Basic Needs' Satisfaction In General Scale. Contemporary Educational Psychology, 35(4): 280-96.

Joosten, T. and Cusatis, R. (2020). Online Learning Readiness. American Journal of Distance Education, 1(5): 1-14. https://doi.org/10.1080/08923647.2020.1726167

Jumaat, N. F. and Tasir, Z. (2014). 'Instructional Scaffolding in Online Learning Environment: A Metaanalysis', international conference on teaching and learning in computing and engineering (IEEE), 74-77.

Kali, Y., Goodyear, P. and Markauskaite, L. (2011). Researching Design Practices and Design Cognition: Contexts, Experiences and Pedagogical Knowledge-In-Pieces. Learning, Media and Technology, 36(2): 129-49. https://doi.org/10.1080/17439884.2011.553621

Kanat-Maymon, Y., Benjamin, M., Stavsky, A., Shoshani, A. and Roth, G. (2015). The Role of Basic Need Fulfillment In Academic Dishonesty: A Self-Determination Theory Perspective. $\begin{array}{llll}\text { Contemporary } \quad \text { Educational } & \text { Psychology, }\end{array}$ https://doi.org/10.1016/j.cedpsych.2015.08.002

Kear, K., Chetwynd, F. and Jefferis, H. (2014). Social Presence in Online Learning Communities: The Role of Personal Profiles. The Journal of the Association for Learning Technology, 22(2): 1-15.

Kim, J. Y. and Lim, K. Y. (2019). Promoting Learning in Online, ill-Structured Problem Solving: The Effects of Scaffolding Type and Metacognition Level. Computers \& Education, 138(6): 116-29. http://dx.doi.org/10.1016/j.compedu.2019.05.001

Kim, K. J., Liu, S. and Bonk, C. J. (2005). Online MBA Students' Perceptions of Online Learning: Benefits, Challenges, and Suggestions. The Internet and Higher Education, 8(4): 335-44.

Krejcie, R. V. and Morgan, D. W. (1970). Determining Sample Size for Research Activities. Educational and Psychological Measurement, 30(3): 607-10.

Lederman, D. (2018). Who Is Studying Online (and where)? Inside Higher Education, 5(2): 1-6. 
Littlefield, J. (2018). The Difference Between Synchronous and Asynchronous Distance Learning. https://www.thoughtco.com/synchronous-distance-learning-asynchronous-distance-learning1097959on7/8/2021

Mahama, I., Asante, F. L., Mensah, J. K., Kwaw, R., Amponsah, M. A., Nartey, P. and Opoku, E. B. (2021). Attached or Not Attached: Does Different Learning Styles Exist Among Students With or Without Sense of Belonging Amidst Covid-19? Journal of Educational Technology and Online Learning, 4(2): 175-92. http://doi.org/10.31681/jetol.905277

Marczuk, A., Multrus, F. and Lörz, M. (2021). The Study Situation in the Corona Pandemic. Effects of Digitization on the Learning and Contact Situation of Students. Hanover: DZHW letter.

McBrien, J. L., Cheng, R. and Jones, P. (2009). Virtual Spaces: Employing A Synchronous Online Classroom to Facilitate Student Engagement in Online Learning. International Review of Research in Open and Distributed Learning, 10(3): 22-31.

McPhee, I. and Söderström, T. (2012). Distance, online and campus higher education: reflections on learning outcomes. Campus-Wide Information Systems, 29(3): 144-55. https://doi.org/10.1108/10650741211243166

Milligan, C. and Littlejohn, A. (2017). Why Study On A MOOC? The Motives of Learners and Professionals. The International Review of Research in Open and Distributed Learning, 18(2): 92-102. http://dx.doi.org/10.19173/irrodl.v18i2.3033

Milyavskaya, M. and Koestner, R. (2011). Psychological Needs, Motivation, and Well-Being: A Test of Self-Determination Theory Across Multiple Domains. Personal. Individual Differences, 50(3): 387-91.

Mueller, B., Mandernach, B. J. and Sanderson, K. (2013). Adjunct Versus Fulltime Faculty: Comparison of Student Outcomes in the Online Classroom. Journal of Online Learning \& Teaching, 9(3): $341-52$.

Mukhtar, K., Javed, K., Arooj, M. and Sethi, A. (2020). Advantages, Limitations and Recommendations For Online Learning During Covid-19 Pandemic Era. Pakistan Journal of Medical Sciences, 36(2): 27-32.

Oliver, R. and Herrington, J. (2003). Exploring Technology-Mediated Learning From A Pedagogical Perspective. Interactive Learning Environments, 11(2): 111-26. https://doi.org/10.1076/ilee.11.2.111.14136

Palmer, S. (2012). Understanding the Context of Distance Students: Differences in On-And Off-Campus Engagement With an Online Learning Environment. Journal of Open, Flexible, and Distance Learning, 16(1): 70-82.

Panigrahi, R., Srivastava, P. R. and Sharma, D. (2018). Online Learning: Adoption, Continuance, and Learning Outcome: A Review of Literature. International Journal of Information Management, 43(5): $1-14$.

Picciano, A. G. (2002). Beyond Student Perceptions: Issues of Interaction, Presence, and Performance in an Online Course. Journal of Asynchronous Learning Networks, 6(1): 21-40.

Prensky, M. (2001). Digital Natives, Digital Immigrants Part 2: Do They Really Think Differently? On The Horizon, 9(6): 1-6. https://doi.org/10.1108/10748120110424843

Rahman, M. H. A., Uddin, M. S. and Dey, A. (2021). Investigating the Mediating Role of Online Learning Motivation in the Covid-19 Pandemic Situation in Bangladesh. Journal of Computer Assisted Learning, 4(5): 1-15.

Roddy, C., Amiet, D. L., Chung, J., Holt, C., Shaw, L., McKenzie, S. and Mundy, M. E. (2017). Applying Best Practice Online Learning, Teaching, and Support to Intensive Online Environments: An Integrative Review. Frontiers in Education, 2(59): 271-83. https://doi.org/10.3389/feduc.2017.00059

Russo, T. C. and Benson, S. (2005). Learning With Invisible Others: Perceptions of Online Presence and Their Relationship To Cognitive and Affective Learning. International Forum of Educational Technology and Society, 8(1): 54-62.

Ryan, R. M. and Deci, E. L. (2000). The Darker and Brighter Sides of Human Existence: Basic Psychological Needs As A Unifying Concept. Psychological Inquiry, 11(4): 319-38.

Schiffrin, H. H., Liss, M., Miles-McLean, H., Geary, K. A., Erchull, M. J. and Tashner, T. (2014). Helping or Hovering? The Effects of Helicopter Parenting on College Students' Well-Being. Journal of Child and Family Studies, 23(3): 548-57. 
Schwinger, M., Trautner, M., Kärchner, H. and Otterpohl, N. (2020). Psychological Impact of Corona Lockdown in Germany: Changes in Need Satisfaction, Well-Being, Anxiety, and Depression. International Journal of Environmental Research and Public Health, 17(23): 9083.

Seaman, J. E., Allen, I. E. and Seaman, J. (2018). Grade Increase: Tracking Online Education in the United States. Babson Survey Research Group: https://onlinelearningsurvey.com/reports/gradeincrease.pdfon7/8/2021

Seyfeli, F., Elsner, L. and Wannemacher, K. (2020). From Corona Shutdown To Blended University? Expert Survey of the Digital Summer Semester. Baden: Tectum Verlag.

Singh, V. and Thurman, A. (2019). How Many Ways Can We Define Online Learning? A Systematic Literature Review of Definitions of Online Learning (1988-2018). American Journal of Distance Education, 33(4): 289-306.

Smyth, E. and Lodge, J. (2012). Orientation Online: Introducing Commencing Students To University Study. A Practice Report. International Journal of the First Year in Higher Education, 3(2): 8390.

Stolk, J. D., Jacobs, J., Girard, C. and Pudvan, L. (2018). 'Learners' Needs Satisfaction, Classroom Climate, and Situational Motivations: Evaluating Self-Determination Theory in an Engineering Context', IEEE Frontiers in Education Conference (FIE) (6), 41-56.

Studitemps GmbH and University., M. (2021). Studying and Earning Money Under Pandemic Conditions - Analysis of the Job Situation and Financial Resources of University Students in Germanycomparison of Summer Semester 2019 and Summer Semester 2020 - Special Evaluation of the Study Series "Specialist 2030. https://studitemps.de/wpcontent/uploads/2020/11/studitemps-whitepaper-jobwelt.pdfon7/8/2021

Tallent-Runnels, M. K., Thomas, J. A., Lan, W. Y., Cooper, S., Ahern, T. C., Shaw, S. M. and Liu, X. (2006). Teaching Courses Online: A Review of the Research. Review of Educational Research, 76(1): 93-135.

Tomei, L., Hagel, H., Rineer, A., Mastandrea, L. A. and Scolon, J. (2009). Do Orientation Materials Help Students Successfully Complete Online Courses? International Journal of Information and Communication Technology Education (IJICTE), 5(2): 73-89.

Traus, A., Höffken, K., Thomas, S., Mangold, K. and Schröer, W. (2020). Students digital in times of corona: First results of the nationwide study. Hildesheim: University Press Hildesheim.

Vansteenkiste, M., Ryan, R. M. and Soenens, B. (2020). Basic Psychological Need Theory: Advancements, Critical Themes, and Future Directions. Motivation and Emotion, 44(1): 1-31.

Vygotsky, L. S. (1978). Mind in Society. Cambridge, MA: Harvard University Press.

Wang, R., Liu, H., Jiang, J. and Song, Y. (2017). Will Materialism Lead To Happiness? A Longitudinal Analysis of the Mediating Role of Psychological Needs Satisfaction. Personality and Individual Differences, 105(2): 312-17.

Wang, Y., Tian, L. and Scott-Huebner, E. (2019). Basic Psychological Needs Satisfaction At School, Behavioral School Engagement, and Academic Achievement: Longitudinal Reciprocal Relations Among Elementary School Students. Contemporary Educational Psychology, 56(3): 130-39.

Wood, D., Bruner, J. S. and Ross, G. (1976). The Role of Tutoring in Problem Solving. Journal of Child Psychology and Psychiatry, 17(2): 89-100.

Yilmaz, F. G. K. and Yilmaz, R. (2019). Impact of Pedagogic Agent-Mediated Metacognitive Support Towards Increasing Task and Group Awareness in CSCL. Computers \& Education, 134(4): 1-14. https://doi.org/10.1016/j.compedu.2019.02.001

Yu, S., Levesque-Bristol, C. and Maeda, Y. (2018). General Need For Autonomy and Subjective WellBeing: A Meta-Analysis of Studies in the US and East Asia. Journal of Happiness Studies, 19(6): 1863-82.

Yu, Z. (2021). The Effects of Gender, Educational Level, and Personality on Online Learning Outcomes During the Covid-19 Pandemic. International Journal of Educational Technology in Higher Education, 18(1): 1-17.

Zhang, K. and Bonk, C. J. (2009). Addressing Diverse Learner Preferences and Intelligences With Emerging Technologies: Matching Models To Online Opportunities. Canadian Journal of Learning and Technology/La revue canadienne de l'apprentissage et de la technologie, 34(2): 1 14. 


\section{APPENDIX}

\section{Dear Respondent,}

We are embarking on study would be grateful if you could answer the questions below. There is no right or wrong answer. I am interested in your personal experience and opinion. The confidentiality of your information is guaranteed.

\section{SECTION A \\ Demographic Data}

1. Gender/Sex: Male [ ] Female [ ]

2. Age...........

\section{SECTION B}

\section{Instruction}

In the tables below for each statement mark how much you agree with a tick $[\sqrt{ }]$ in the box to the right of each statement. The responses are on the scale Strongly Disagree [SD], Disagree [D], Agree [A] and Strongly Agree [SA].

\section{Instruction}

In the tables below for each statement mark how much you agree with a tick $[\sqrt{ }]$ in the box to the right of each statement. The responses are on the scale 1 to 7.

\section{Online Instructional Scaffolding}

\begin{tabular}{|c|c|c|c|c|c|c|c|}
\hline Statements & 1 & 2 & 3 & 4 & 5 & 6 & 7 \\
\hline 1. My tutors encourage students to ask questions. & & & & & & & \\
\hline 2. My instructor provides regular feedback on student interactions. & & & & & & & \\
\hline 3. My tutors promptly respond to students' needs or requests. & & & & & & & \\
\hline $\begin{array}{l}\text { 4. My tutors are positive and supportive of students' comments to } \\
\text { encourage students to continue participating in online interactions. }\end{array}$ & & & & & & & \\
\hline $\begin{array}{l}\text { 5. My tutors provide regular announcements with students to } \\
\text { communicate clearly what they expect in interaction activity. }\end{array}$ & & & & & & & \\
\hline 6. My tutors monitor how we interact with each other. & & & & & & & \\
\hline $\begin{array}{l}\text { 7. My tutors provide basic guidelines to help students become aware } \\
\text { of the importance of classroom interaction. }\end{array}$ & & & & & & & \\
\hline $\begin{array}{l}\text { 8. My tutors leave a message to thank students for contribution to } \\
\text { classroom interactions. }\end{array}$ & & & & & & & \\
\hline $\begin{array}{l}\text { 9. My tutors actively participate in classroom discussion by replying } \\
\text { to students, summarizing discussion, or asking questions to } \\
\text { students. }\end{array}$ & & & & & & & \\
\hline $\begin{array}{l}\text { 10. Whenever posting a message, my tutors encourage students to } \\
\text { share their concern or problems with them. }\end{array}$ & & & & & & & \\
\hline 11. My tutors provide timelines for students' classroom interactions. & & & & & & & \\
\hline $\begin{array}{l}\text { 12. If students' general interaction is low, my tutors encourage us to } \\
\text { participate actively in interaction by sending a note. }\end{array}$ & & & & & & & \\
\hline
\end{tabular}

\section{SECTION C}

\section{Instruction}

In the tables below for each statement mark how much you agree with a tick $[\sqrt{ }]$ in the box to the right of each statement. The responses are on the scale 1 to 7.

\section{Basic Need Satisfaction Scale}

\section{Statements}

1. I feel like I am free to decide for myself how to live my life in school.

2. I generally feel free to express my ideas and opinions in school. 
3. I feel like I can pretty much be myself in my daily situations in school.

4. Often, I do not feel very competent in school.

5. People I know tell me I am good at what I do in school.

6. I have been able to learn interesting new skills recently in school.

7. Most days I feel a sense of accomplishment from what I do in school.

8. In my life I do not get much of a chance to show how capable I am in school.

9. I often do not feel very capable in school.

10. I really like the people I interact with in school.

11. I get along with people I come into contact with in school.

12. 24. I pretty much keep to myself and do not have a lot of social contacts in school.

13. I consider the people I regularly interact with to be my friends in school.

14. People in my life care about me in school

15. The people I interact with regularly do not seem to like me much in school

16. People are generally pretty friendly towards me in school.

17. I feel pressured in my life in school.

18. In my daily life, I frequently have to do what I am told to do in school.

19. People I interact with on a daily basis tend to take my feelings into consideration.

20. There are no many people that I am close to in school.

21. There is not much opportunity for me to decide for myself how to do things in my daily life in school. 